\title{
PREVALENSI DAN TINGKAT KONTAMINASI Listeria monocytogenes DI TAMBAK DAN UNIT PENGOLAHAN UDANG VANAME (Litopenaeus vannamei) UNTUK PASAR EKSPOR
}

\section{Prevalence and Contamination Level of Listeria monocytogenes in Culture and Processing Plant of Shrimp (Litopenaeus vannamei) for Export Market}

\author{
Yusma Yennie*, Gunawan, dan Farida Aryani \\ Balai Besar Riset Pengolahan Produk dan Bioteknologi Kelautan dan Perikanan, \\ Jl. KS Tubun, Petamburan VI, Jakarta Pusat, DKI Jakarta, 10260, Indonesia \\ *Korespondensi penulis : yenni.yusma@gmail.com \\ Diterima: 8 Oktober 2020; Direvisi: 21 Mei 2021 ; Disetujui: 19 Oktober 2021
}

\begin{abstract}
ABSTRAK
Listeria monocytogenes adalah salah satu bakteri patogen yang dapat menyebabkan penyakit bawaan pangan. Penolakan ekspor produk udang beku Indonesia karena kontaminasi $L$. monocytogenes masih terjadi yang berdampak pada kerugian material bagi pelaku usaha. Tujuan penelitian ini adalah untuk mengetahui prevalensi dan tingkat kontaminasi $L$. monocytogenes pada produk udang beku untuk pasar ekspor. Sampel yang diambil merupakan udang segar dari tambak dan bahan baku dari bagian penerimaan di Unit Pengolahan Ikan (UPI) serta udang beku sebagai produk akhir UPI, dengan menerapkan sistem ketertelusuran. Lokasi penelitian adalah Sumatra Utara (Medan), DKI Jakarta, Jawa Timur (Surabaya dan Banyuwangi), dan Sulawesi Selatan (Makassar). Identifikasi dan enumerasi L. monocytogenes dilakukan dengan metode MPN-PCR dengan target gen hlyA ( 456bp). Prevalensi L. monocytogenes pada udang vaname secara keseluruhan sebesar $6,7 \%$ (9/135 sampel), dengan prevalensi di masing-masing titik pengambilan sampel berturut-turut $6,1 \%$ di tambak, 9,6\% di bahan baku, dan $4 \%$ di produk akhir, yang merupakan sampel udang dari batch yang sama. Tingkat kontaminasi $L$. monocytogenes pada sampel udang vaname berkisar 6,1-1.100 APM/g. Persyaratan L. monocytogenes pada bahan pangan adalah negatif/25g, sehingga sampel udang yang terkontaminasi $L$. monocytogenes tersebut tidak memenuhi persyaratan sebagai pangan yang aman untuk dikonsumsi berdasarkan regulasi yang berlaku di Indonesia maupun di negara lain. Kontaminasi $L$. monocytogenes pada udang beku kemungkinan berasal dari tambak ataupun lingkungan pengolahan. Penerapan Good Aquaculture Practices (GAP) di lingkungan tambak udang, serta Hazard Analysis Critical Control Point (HACCP) dan Good Manufacturing Practices (GMP) di UPI perlu dilakukan dengan benar sebagai upaya pengendalian kontaminasi L. monocytogenes. Selain itu, perlu dilakukan kajian lebih lanjut mengenai sumber dan titik kritis kontaminasi L. monocytogenes di sepanjang rantai pengolahan udang beku mulai dari tambak sampai produk akhir.
\end{abstract}

KATA KUNCI : Listeria monocytogenes, udang vaname, prevalensi, tambak, unit pengolahan ikan

\begin{abstract}
Listeria monocytogenes is pathogenic bacteria that can cause foodborne illness. Rejection of frozen shrimp exports due to L. monocytogenes contamination still occurs and causes economical losses for the industries. The objective of this study was to determine the prevalence and the level of $\underline{L}$. monocytogenes contamination in frozen shrimp for export markets. Samples collected were fresh shrimp from shrimp culture and raw material from the receiving point of fish processing plants (UPI), and frozen shrimp as the end product, by implementing a traceability system. Study locations were in North Sumatra (Medan), Special Capital Region of Jakarta, East Java (Surabaya dan Banyuwangi), and South Sulawesi (Makassar). Identification and enumeration of $\underline{L}$. monocytogenes were carried out using the MPN-PCR method with the target gene hlyA ( 456bp). The prevalence of $L$. monocytogenes in vanname shrimp was $6.7 \%$ (9 out of 135 samples), where $6.1 \%, 9.6 \%$, and $4 \%$ of the prevalence were found in samples from shrimp culture, raw material, and end product, respectively. These samples were from the same batch. The contamination level ranged from 6.1 to $1,100 \mathrm{MPN} / \mathrm{g}$. L. monocytogenes in food should be negative $/ 25 \mathrm{~g}$, thus the contaminated samples do not meet requirements as safe for human consumption based on food
\end{abstract}


regulation in Indonesia and other countries. Findings from this study suggested that shrimp culture or fish processing environment are potential sources of $L$. monocytogenes contamination in frozen shrimp. Therefore, the implementation of Good Aquaculture Practices (GAP) in shrimp culture environment, as well as Hazard Analysis Critical Control Point (HACCP) and Good Manufacturing Practices (GMP) in shrimp processing plant are necessary to control $\underline{L}$. monocytogenes contamination. Further studies regarding the sources and critical points of $\underline{L}$. monocytogenes contamination throughout the processing of frozen shrimp from shrimp culture to end product are also needed.

\section{KEYWORDS: Listeria monocytogenes, vanname shrimp, prevalence, shrimp culture, fish processing plant}

\section{PENDAHULUAN}

Listeria monocytogenes merupakan bakteri patogen penyebab penyakit bawaan pangan yang dapat ditemukan pada udang, karena merupakan bakteri yang hidup di lingkungan perairan laut dan estuari yang merupakan habitat udang (Gram, 2001; Zhu, Du, Cordray, \& Ahn, 2005). Bakteri ini memiliki karakteristik dapat beradaptasi di lingkungan yang memiliki suhu, $\mathrm{pH}$, ataupun aktivitas air $\left(\mathrm{a}_{\mathrm{w}}\right)$ yang rendah (Gandhi \& Chikindas, 2007). L. monocytogenes umum ditemukan di dalam pangan siap saji, terutama pangan mentah atau pangan dengan proses pengolahan minimal seperti sushi, ikan yang menggunakan pengasapan dingin (cold-smoked fish) serta produk yang mengalami penyimpanan dalam jangka waktu lama sebelum dikonsumsi (Beaufort et al. 2007; Calo-Mata et al. 2008; Ghanbari, Jami, Domig, \& Kneifel, 2013). Kontaminasi $L$. monocytogenes di produk pangan dapat mengakibatkan listeriosis, yaitu gangguan kesehatan seperti gastroenteritis, demam, keguguran pada ibu hamil, septisemia, pneumonia, meningitis, dan lainnya (Franciosa, Tartaro, Wedell-Neergaard, \& Aureli, 2001; Sotgiu et al. 2019). Kasus listeriosis jarang terjadi namun memiliki tingkat kematian yang tinggi, yaitu 20-30\% (Esteban, Oporto, Aduriz, Juste \& Hurtado, 2009; Palumbo, lannacone, Porta, \& Capparelli, 2010).

Keberadaan L. monocytogenes pada produk perikanan seperti udang beku dipengaruhi oleh faktor lingkungan, musim, proses penanganan, pengolahan, sampai dengan penyimpanan produk sebelum dikonsumsi (Gambarin et al., 2012; Jami, Ghanbari, Zunabovic, Domig, \& Kneifel, 2014). Kontaminasi di unit pengolahan memiliki pola tertentu, walaupun menggunakan bahan baku yang sama (Lappi, Ho, Gall, \& Wiedmann, 2004; Thimothe, Nightingale, Gall, Scott, \& Wiedmann, 2004). Prevalensi L. monocytogenes pada produk udang telah banyak dilaporkan di berbagai negara, dengan angka berkisar 1,5-28,8\% (Beleneva 2011; Fallah, Saei-Dehkordi, \& Mahzounieh, 2013; Gawade, Barbuddhe, \& Bhosle,
2010; Jami et al., 2014; Wang et al., 2011; Yadollahi, Momtaz, Doudi, \& Taj bakhsh, 2013), namun informasi terkait dari Indonesia masih terbatas. Hasil penelitian L. monocytogenes pada produk perikanan pernah dilaporkan oleh Yuswita, Nurjanah, dan Rahayu (2016) pada pangan jajanan berbasis ikan di Kota Bogor, dan tidak ditemukan kontaminasi $L$. monocytogenes pada produk tersebut. Keberadaan L. monocytogenes juga tidak ditemukan di sampel kerang hijau dan kerang darah segar di wilayah Bogor seperti yang dilaporkan oleh Rahayu, Rinanti, Nurjanah, dan Nurwitri (2016). Hal ini bukan berarti kontaminasi bakteri ini tidak ditemukan, tetapi penelitian terkait masih perlu dilakukan secara komprehensif dan mencakup jenis sampel yang lebih bervariasi.

Pada tahun 2012-2013, Badan Karantina Ikan, Pengendalian Mutu dan Keamanan Hasil Perikanan (BKIPM) melaporkan sebanyak 2 kasus penolakan ekspor komoditas udang ke Amerika Serikat terkait kontaminasi Listeria yang menunjukkan masih adanya kontaminasi $L$. monocytogenes pada produk udang beku dari Indonesia. Penelitian ini bertujuan untuk mengetahui prevalensi dan tingkat kontaminasi $L$. monocytogenes di dalam satu alur pengolahan udang beku untuk pasar ekspor yang diperoleh dari tambak, bagian penerimaan, dan pembekuan udang di Unit Pengolahan Ikan (UPI), dengan menerapkan sistem ketertelusuran.

\section{BAHAN DAN METODE}

\section{Pengambilan Sampel}

Sampel yang digunakan adalah udang vaname (Litopenaeus vannamei) dalam bentuk segar yang diperoleh dari tambak dan bagian penerimaan bahan baku di UPI, dan udang dalam bentuk beku yang merupakan produk akhir dari UPI. Udang dari tambak adalah udang siap panen yang berumur sekitar 60 hari dengan berat berkisar 20-25 g/ekor (ukuran 40-50 
ekor $/ \mathrm{kg}$ ). Sampel udang vaname yang diambil dari tambak, dari bagian penerimaan bahan baku di UPI, dan dari bagian akhir proses pembekuan di UPI merupakan udang yang berasal dari batch yang sama. Pengambilan sampel tersebut dilakukan secara tertelusur. Pengambilan sampel dilakukan pada bulan Mei-November 2015 di Sumatra Utara (Medan), DKI Jakarta, Jawa Timur (Surabaya dan Banyuwangi) dan Sulawesi Selatan (Makasar). Penentuan lokasi ini berdasarkan rekomendasi dari BKIPM sebagai wilayah dengan volume produksi dan ekspor terbesar di Indonesia. Wawancara dengan pelaku usaha, yaitu petani tambak, pengepul, dan pihak UPI dilakukan untuk memperoleh informasi tentang rantai pasok pengolahan udang beku mulai dari tambak sebagai asal bahan baku sampai dengan produk akhir di UPI.

Sampel udang segar dari tambak berasal dari 11 tambak (masing-masing 3 tambak di wilayah Surabaya dan Banyuwangi, serta 5 tambak di wilayah Makassar). Pengambilan sampel udang dari tambak di lokasi Medan dan DKI Jakarta tidak dilakukan karena pihak petambak atau pemasok tidak memberikan izin untuk melakukan pengambilan sampel. Pengambilan sampel di bagian penerimaan bahan baku dan produk akhir dilakukan di 17 UPI yang terdiri atas 3 di wilayah Medan, 2 di DKI Jakarta, 4 di Surabaya, 4 di Banyuwangi, dan 4 di Makassar. Total udang yang diperoleh sebanyak 135 sampel yang terdiri atas 33 sampel dari tambak, 52 sampel dari bagian penerimaan di UPI, dan 50 sampel adalah produk akhir di bagian proses pembekuan di UPI.

Pengambilan sampel di tambak, dilakukan dengan 1 kali kunjungan ke lokasi tambak saat pemanenan udang. Sampel diambil di 5 titik di setiap petakan tambak yang dikomposit menjadi 1 unit sampel dengan berat sekitar $500 \mathrm{~g}$. Pengambilan sampel di setiap petakan tambak dilakukan dengan 3 kali ulangan. Untuk sampel bahan baku dari bagian penerimaan dan produk akhir di UPI, diambil secara acak yang dikomposit menjadi 1 unit sampel dengan berat sekitar $500 \mathrm{~g}$. Pengambilan sampel diulang sebanyak 3 kali. Sampel diambil secara aseptis sesuai dengan prosedur pengambilan sampel untuk pengujian mikrobiologi dan disimpan dalam plastik steril secara terpisah dan ditempatkan di dalam cool box dan diberi es, kemudian dibekukan dan dibawa ke laboratorium untuk dilakukan identifikasi dan enumerasi $L$. monocytogenes.

\section{Isolasi dan Enumerasi L. monocytogenes}

Isolasi L. monocytogenes mengacu pada SNI ISO 11290-1 (SNI ISO, 2012) dengan modifikasi pada tahap konfirmasi dengan metode PCR (PaziakDomanèska et al., 1999). Sampel udang sebanyak
$25 \mathrm{~g}$ ditimbang dan ditambahkan ke dalam $225 \mathrm{ml}$ media half fraser (Oxoid, England) dan dihomogenisasikan menggunakan stomacher 200 rpm selama 1 menit. Homogenat diinkubasi pada suhu $30 \pm 1^{\circ} \mathrm{C}$ selama $24 \pm 2 \mathrm{jam}$. Homogenat dari media half fraser diinokulasikan sebanyak $0,1 \mathrm{ml}$ ke dalam $10 \mathrm{ml}$ media fraser broth (Oxoid, England) dan diinkubasi pada suhu $37 \pm 1^{\circ} \mathrm{C}$ selama $48 \pm 3$ jam. Sampel selanjutnya diinokulasikan pada media agar selektif PALCAM (Oxoid, England), lalu diinkubasi pada $37 \pm 1^{\circ} \mathrm{C}$ selama $24 \pm 3$ jam. Koloni tipikal $L$. monocytogenes yang tumbuh di media PALCAM diinokulasikan ke media agar miring tryptone soy yeast extract (Oxoid, England) dan diinkubasi pada suhu $37^{\circ} \pm 1^{\circ} \mathrm{C}$ selama $24 \pm 2$ jam, selanjutnya digunakan pada tahap konfirmasi dengan PCR.

Enumerasi L. monocytogenes menggunakan metode MPN dengan serial 3 tabung yang diadaptasi dari penelitian Chen, Wu, Zhang, Wu, dan Guo (2015). Enumerasi dilakukan dengan serial pengenceran 10 ${ }^{1}-10^{-3}$. Sebanyak $1 \mathrm{ml}$ homogenat dari media half fraser diinokulasikan ke setiap pengenceran yang masingmasing terdiri atas 3 tabung dan dinkubasi pada $30 \pm 2^{\circ} \mathrm{C}$ selama $24 \pm 2$ jam. Masing-masing tabung homogenat dipindahkan sebanyak $0,1 \mathrm{ml}$ ke dalam tabung yang berisi $10 \mathrm{ml}$ media fraser broth dan diinkubasi pada $30 \pm 2^{\circ} \mathrm{C}$ selama $26 \pm 2$ jam. Tabung yang media fraser brothnya berubah menjadi gelap, selanjutnya diinokulasikan ke media agar selektif PALCAM untuk dilakukan konfirmasi dengan metode PCR, sedangkan tabung yang media fraser brothnya belum mengalami perubahan, diinkubasi kembali pada suhu $30 \pm 2^{\circ} \mathrm{C}$ selama $26 \pm 2$ jam. Perhitungan jumlah bakteri mengacu pada tabel nilai MPN seri 3 tabung yang diadaptasi dari FDA-BAM (Hitchins, 2003).

\section{Konfirmasi L. monocytogenes}

Konfirmasi L. monocytogenes diawali dengan tahap ekstraksi DNA genom dari isolat tipikal $L$. monocytogenes menggunakan protokol kit ekstraksi DNA TIANamp genomic DNA kit (Tiangen, China). Amplifikasi DNA hasil ekstraksi dilakukan menggunakan target gen hlyA ( 456bp) dengan pasangan primer adalah hlyA-F (5'GCAGTTGCAAGCGCTTGGAGTGAA-3') dan (5'GCAACGTATCCTCCAGAGTGATCG-3') untuk hlyA-R (Paziak-Domanska et al., 1999). Gen hlyA merupakan gen virulensi, terdapat pada bakteri L. monocytogenes patogenik yang mengkode listeriolisin O (LLO) dan membedakannya dengan jenis Listeria lainnya (Aznar \& Alarcón, 2003; Jadhav, Bhave \& Palombo, 2012).

Reaksi PCR yang digunakan memiliki volume akhir $25 \mu \mathrm{L}$, terdiri atas campuran reaktan $12,5 \mu \mathrm{L}$ DreamTaq Hot Start Green PCR Master Mix (Thermo Scientific, USA), masing-masing $1 \mu \mathrm{L}$ primer gen hlyA 
(forward dan reverse), $1 \mu \mathrm{L}$ DNA sampel, dan 9,5 $\mu \mathrm{L}$ nuclease free water (Thermo Scientific, USA) dengan protokol amplifikasi menggunakan thermal cycler (Biorad, USA) pada kondisi pra denaturasi $\left(95^{\circ} \mathrm{C}, 120\right.$ detik), denaturasi $\left(95^{\circ} \mathrm{C}, 15\right.$ detik), penempelan primer $\left(60^{\circ} \mathrm{C}, 30\right.$ detik), elongasi atau pemanjangan primer $\left(72^{\circ} \mathrm{C}, 90\right.$ detik $)$ dan elongasi akhir $\left(72^{\circ} \mathrm{C}, 600\right.$ detik $)$ dengan siklus sebanyak 35 kali (Paziak-Domanska et al. 1999). Produk PCR diamati dengan elektroforesis gel (tegangan $100 \mathrm{~V}$; kuat arus $50 \mathrm{~mA}$ ) menggunakan $1,5 \%$ gel agarose dan bufer TBE1X selama 35 menit, selanjutnya dilakukan pewarnaan dengan SYBR gold nucleic acid gel stain (Invitrogen, USA) dan divisualisasikan dengan UV-transilluminator (Biorad, USA). Konfirmasi L. monocytogenes pada sampel udang menggunakan bakteri $L$. monocytogenes ATCC 19114 sebagai kontrol positif dan bakteri Salmonella enterica ATCC 13076 sebagai kontrol negatif.

\section{HASIL DAN PEMBAHASAN}

Berdasarkan hasil wawancara dengan pihak petani tambak, pengumpul, dan UPI pada penelitian ini, diketahui bahwa rantai pasok pengolahan udang beku mulai dari tambak sampai dengan produk akhir di UPI seperti yang tersaji di Gambar 1. Rantai dimulai dari pemanenan udang di tambak, dilanjutkan dengan kegiatan sortasi, pencucian, dan penimbangan udang di area tambak. Udang hasil sortasi dimasukkan ke dalam wadah plastik dan dilakukan pengesan untuk mempertahankan suhu rendah $\left(<4^{\circ} \mathrm{C}\right)$. Selanjutnya udang ditransportasikan ke pengepul . Udang disimpan sementara di pengepul sampai jumlah kebutuhan udang oleh UPI terpenuhi, dan selama penyimpanan dilakukan pengesan. Pengiriman udang selanjutnya dilakukan oleh pengepul ke UPI dan diterima di bagian penerimaan bahan baku. Saat transportasi udang yang dilakukan oleh pengepul, suhu udang dipertahankan rendah $\left(<4^{\circ} \mathrm{C}\right)$ untuk mempertahankan mutu udang. Bahan baku udang segar selanjutnya dilakukan proses pengolahan dan menghasilkan produk akhir dalam bentuk udang beku. Gambaran ini merupakan rantai pasok pengolahan udang beku yang secara umum berlaku di Indonesia.

Secara keseluruhan prevalensi L. monocytogenes di udang vaname pada penelitian ini sebesar 6,7\% (9/ 135 sampel) dengan tingkat kontaminasi berkisar 6,1$1.100 \mathrm{APM} / \mathrm{g}$ (Tabel 1). Prevalensi L. monocytogenes pada udang yang ditemukan pada penelitian ini relevan dengan beberapa laporan hasil penelitian lain baik

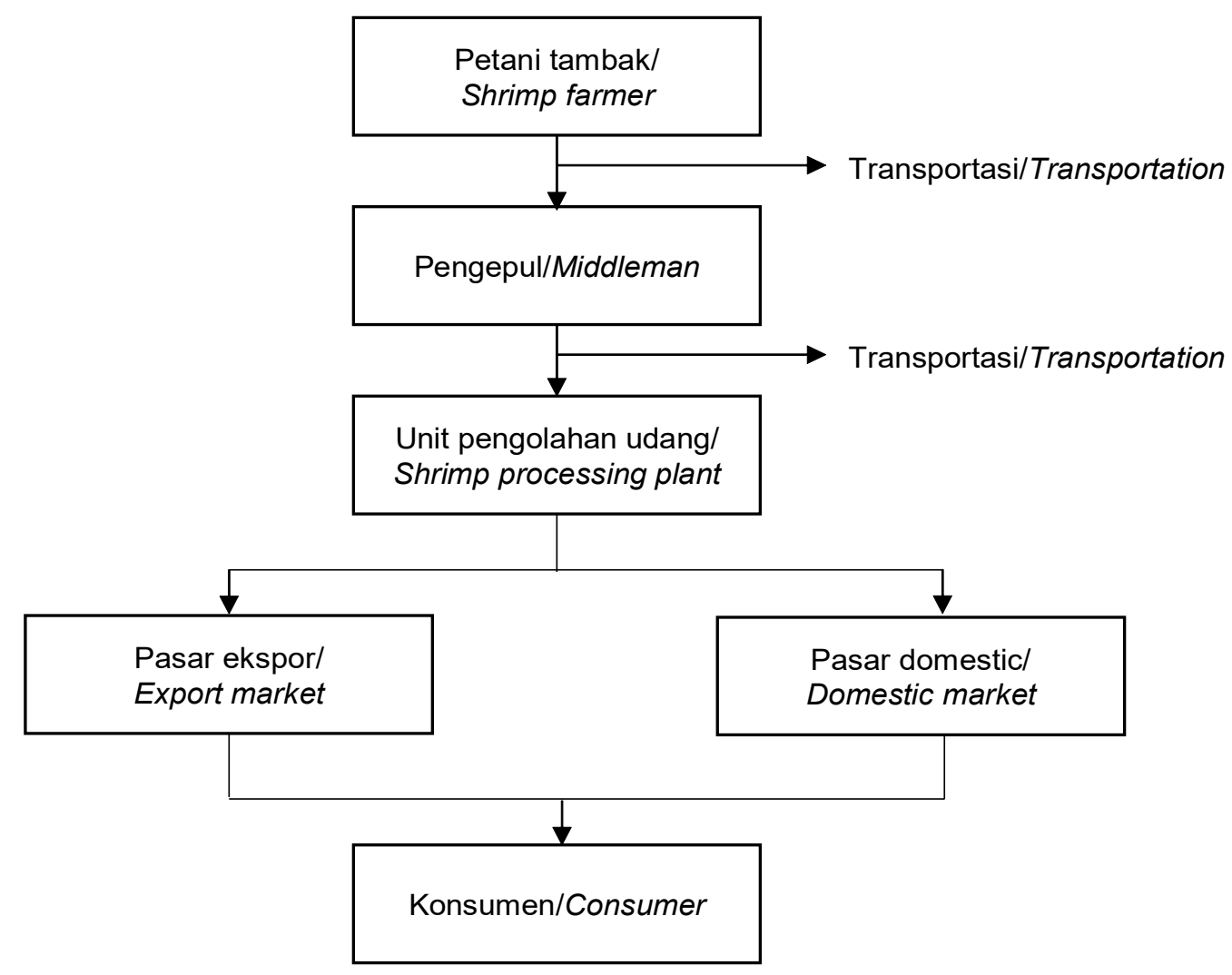

Gambar 1. Rantai pengolahan udang beku di Indonesia

Figure 1. Frozen shrimp processing chain in Indonesia 
udang hasil budidaya maupun udang tangkapan yaitu berkisar 1,5-28,8\% (Cordano \& Rocourt, 2001; Fallah et al., 2013; Gawade et al., 2010; Gudmundsdóttir, Gudbjörnsdóttir, Einarsson, Kristinsson, \& Kristjansson, 2006; Moharem, Charith Raj \& Janardhan, 2007; Parihar, Barbuddhe, DanielssonThm, \& Tham, 2008; Wang et al., 2011; Yadollahi et al., 2013). Hasil studi epidemiologi tentang bakteri $L$. monocytogenes juga menyebutkan bahwa udang adalah salah satu pangan yang diduga sebagai penyebab kasus listeriosis (Riedo et al., 1994).

Kontaminasi L. monocytogenes pada penelitian ini terdeteksi pada sampel udang dari tambak, bahan baku di bagian penerimaan, dan produk akhir di bagian pembekuan di UPI, yang berasal dari batch yang sama. Hal ini menunjukkan kontaminasi $L$. monocytogenes kemungkinan bersumber dari area budidaya udang karena merupakan salah satu habitat bakteri ini. L. monocytogenes merupakan bakteri psikrotropik, sehingga memungkinkan bakteri ini tetap hidup selama penanganan udang yang menggunakan es. Lingkungan dan peralatan pengolahan di UPI yang tidak memenuhi standar sanitasi dan higiene juga memungkinkan terjadinya kontaminasi, karena $L$. monocytogenes mampu bertahan hidup dan memiliki kemampuan membentuk biofilm.

\section{Prevalensi Listeria monocytogenes di Tambak Udang}

Pada penelitian ini diketahui bahwa prevalensi $L$ monocytogenes di udang yang berasal dari tambak
$(6,1 \%)$ lebih rendah dari yang pernah dilaporkan oleh Motes (1991), yaitu sebanyak $11 \%$ udang yang berasal dari beberapa lokasi di wilayah Gulf Coast, USA terkonfirmasi $L$. monocytogenes. Prevalensi $L$. monocytogenes pada produk perikanan hasil budidaya selain di Indonesia, juga pernah dilaporkan dan diketahui berkisar 0-34\% (Bhaskar et al., 1998; Gram, 2001; Gudmundsdóttir et al., 2006; Hansen, Vogel \& Gram, 2006).

Tambak udang vaname umumnya menggunakan sumber air yang berasal dari perairan laut dan sungai, yang diketahui menjadi salah satu sumber keberadaan bakteri L. monocytogenes di lingkungan tambak. Hal ini karena air membawa material-material seperti hasil vegetasi tanaman, feses hewan dan limbah manusia yang merupakan habitat L. monocytogenes (Embarek 1994; El-Shenawy \& El-Shenawy, 2006; Lyautey et al., 2007; Miettinen \& Wirtanen, 2005, 2006).

Selain itu sedimen juga dapat menjadi sumber kontaminasi L. monocytogenes di lingkungan budidaya dan bakteri ini diketahui mampu bertahan hidup dalam jangka waktu yang lama di sedimen (Botzler, Cowan, \& Wetzler, 1974; Miettinen \& Wirtanen, 2006; Schaffter \& Parriaux, 2002). Kondisi lingkungan yang lembab pada bagian dasar tambak memberikan proteksi dan sumber nutrisi sehingga memungkinkan $L$. monocytogenes bertahan hidup (Fenlon, 1999). Pada penelitian ini tambak udang vaname yang menjadi tempat pengambilan sampel rata-rata memiliki dasar tambak dari tanah yang merupakan habitat $L$. monocytogenes. Hites et al.

Tabel 1. Prevalensi dan tingkat kontaminasi $L$. monocytogenes pada udang

Table 1. Prevalence and contamination level of $\underline{L}$. monocytogenes in shrimp

\begin{tabular}{lccc}
\hline \multicolumn{1}{c}{ Asal Sampel/Sample Origin } & $\begin{array}{c}\text { Jumlah } \\
\text { Sampel/ } \\
\text { No. of } \\
\text { Sample }\end{array}$ & $\begin{array}{c}\text { Jumlah Sampel } \\
\text { Positifl } \\
\text { No. of Positive } \\
\text { Sample (\%) }\end{array}$ & $\begin{array}{c}\text { Tingkat Kontaminasi } \\
\text { (APM/g)/ } \\
\text { Contamination Levels } \\
\text { (MPN/g) }\end{array}$ \\
\hline $\begin{array}{l}\text { Tambak (udang segar)/Shrimp culture } \\
\text { (fresh shrimp) }\end{array}$ & 33 & $2 / 33(6.1)$ & $6.1-150$ \\
$\begin{array}{l}\text { Bahan baku dari bagian penerimaan di } \\
\begin{array}{l}\text { UPI (udang segar)/Raw material from } \\
\text { the receiving point of the processing } \\
\text { plant (fresh shrimp) }\end{array}\end{array}$ & 52 & $5 / 52(9.6)$ & $9.2-1,100$ \\
$\begin{array}{l}\text { Produk akhir dari bagian proses } \\
\text { pembekuan di UPI (udang beku)/End } \\
\text { product from the freezing point of the } \\
\text { processing plant (frozen shrimp) }\end{array}$ & 50 & $2 / 50(4)$ & $240-1,100$ \\
\hline Total/Total & 135 & $9 / 135(6.7)$ & \\
\hline
\end{tabular}

Keterangan/Note: Persyaratan L. monocytogenes pada produk perikanan (termasuk udang beku): negatif/25 g/ Requirements of $\underline{L}$. monocytogenes presence in fishery products (including frozen shrimp): negative/25 g (BPOM, 2019) 
(2004) menyatakan bahwa kontaminasi patogen di lingkungan budidaya merupakan permasalahan penting karena berdampak terhadap komoditas budidaya dan berpotensi menimbulkan risiko pada produk yang dihasilkan oleh industri pengolahan.

Informasi tentang keberadaan $L$. monocytogenes di lingkungan budidaya udang masih terbatas (Norhana, Pool, Deeth \& Dykes, 2010), terutama di wilayah yang beriklim tropis seperti Indonesia. Embarek (1994) melaporkan bahwa prevalensi $L$. monocytogenes di udang lebih tinggi ditemukan di wilayah beriklim sedang (4-12\%) dibandingkan wilayah dengan iklim tropis $(0-2 \%)$, namun beberapa hasil penelitian lain menunjukkan bahwa prevalensi $L$. monocytogenes di produk udang dari wilayah tropis sama dengan wilayah dengan iklim sedang (Norhana et al., 2010). Prevalensi L. monocytogenes pada produk perikanan di beberapa wilayah tropis pernah dilaporkan, seperti di Brazil dengan kisaran 17-18\% (Destro, Leitao, \& Farber, 1996), India sebesar 6,7\% (Moharem et al., 2007), dan Malaysia sebesar 44\% (Arumugaswamy, Ali, \& Abd Hamid, 1994).

\section{Prevalensi Listeria monocytogenes di Bahan Baku}

Berdasarkan hasil wawancara dengan pihak UPI, petambak, maupun pengepul, diperoleh informasi bahwa UPI memperoleh bahan baku udang vaname dengan cara langsung membeli ke petani tambak atau dari pengepul yang mendapatkan udang dari beberapa petani tambak. Sistem pengadaan udang vaname secara langsung dari petani tambak ditemukan di UPI yang berlokasi di DKI Jakarta dan Jawa Timur, bahkan terdapat UPI yang memiliki tambak sendiri. Untuk UPI yang berlokasi di Sulawesi Selatan umumnya memperoleh udang vaname dari pengepul.

Sampel udang yang terdeteksi $L$. monocytogenes di bagian penerimaan bahan baku merupakan sampel dalam batch yang sama dengan udang yang berasal dari tambak, dan prevalensinya lebih tinggi dibandingkan dengan sampel udang asal tambak, sehingga kontaminasi ini kemungkinan terjadi sejak dari tambak. Penerapan sistem rantai dingin yang diterapkan mulai dari udang dipanen dari tambak, saat penyimpanan di pengepul, dan transportasi udang sampai ke UPI, kemungkinan dapat mempertahankan keberadaan $L$. monocytogenes, karena kemampuan bakteri tumbuh di suhu refrigerasi (Beaufort et al., 2007; Zhu et al., 2005). Bakteri L. monocytogenes diketahui mampu bertahan hidup pada suhu rendah dan dikenal sebagai bakteri psikrotropik, sehingga perlakuan suhu rendah dapat memicu pertumbuhan bakteri ini pada bahan pangan (Liu, Mou, \& Su, 2016). Hasil penelitian ini sejalan dengan hasil penelitian
Gudmundsdóttir et al. (2006), bahwa sebanyak 20,9\% (9/43 sampel) udang di bagian penerimaan bahan baku terkonfirmasi $L$. monocytogenes, bahkan bakteri ini terdeteksi di cangkang udang sebanyak 16,7\% (3/18 sampel) di dua UPI. Selain itu, kontaminasi $L$. monocytogenes di bagian penerimaan bahan baku dapat bersumber dari lingkungan dan peralatan pengolahan di area tersebut (Thimothe et al., 2004; Wulff, Gram, Ahrens, \& Vogel 2006).

\section{Prevalensi Listeria monocytogenes di Produk Akhir}

Kontaminasi L. monocytogenes terdeteksi di udang beku yang merupakan produk akhir UPI. Sampel udang ini berasal dari batch yang sama dengan udang dari tambak dan penerimaan bahan baku. Selain dari tambak, L. monocytogenes dapat mengontaminasi produk selama proses pengolahan, yang kemungkinan dapat berasal dari lingkungan pengolahan, peralatan pengolahan, serta personil yang terlibat selama pengolahan (Gudbjörnsdóttir et al., 2004; Gudmundsdóttir et al., 2005; Lappi et al., 2004; Norton et al., 2001; Rørvik, Caugant, \& Yndestad, 1995; Rørvik, 2000; Thimothe et al., 2002; Thimothe et al., 2004).

Peralatan pengolahan seperti pisau, ban berjalan, saluran air, dan lantai merupakan sumber kontaminasi tertinggi $L$. monocytogenes di area pengolahan produk perikanan, karena beberapa strain L. monocytogenes yang persisten tidak dapat hilang setelah dilakukan pembersihan pada area dan peralatan pengolahan (Vogel, Huss, Ojeniyi, Ahrens \& Gram, 2001; Wulff et al. 2006). Selain itu, kemampuan L. monocytogenes berkolonisasi di lingkungan pengolahan dan membentuk biofilm, memungkinkan bakteri ini menempel dan bertahan hidup pada kondisi stres sekalipun seperti di permukaan fasilitas pengolahan pangan, dan kondisi ini yang menyebabkan pangan terkontaminasi selama pengolahan (Chaturongkasumrit, Takahashi, Keeratipibul, Kuda, \& Kimura 2011; Yan et al., 2010). Namun demikian, dalam penelitian ini pengamatan hanya difokuskan pada komoditas udang dan tidak dilakukan pengamatan pada peralatan di lingkungan UPI. Oleh karena itu, diperlukan pengamatan yang lebih komprehensif untuk mendapatkan informasi yang lebih jelas terkait dengan asal kontaminasi $L$. monocytogenes pada pengolahan produk udang beku.

Transmisi kontaminasi L. monocytogenes melalui area pengolahan produk belum sepenuhnya dipahami, namun alur ini menjadi informasi penting dalam menelusuri terjadinya kontaminasi bahkan kasus keracunan akibat pangan (Miettinen \& Wirtanen 2006). Salah satu metode penelusuran yang dilakukan 
adalah dengan mengidentifikasi sub tipe spesies $L$. monocytogenes yang ditemukan di bahan pangan mulai dari bahan baku, proses pengolahan dan produk akhir, jika ditemukan sub tipe $L$. monocytogenes yang sama maka kemungkinan prevalensi bakteri ini pada produk akhir berasal dari bahan baku (Nakamura et al., 2006; Norton et al., 2001; Vogel, et al., 2001; Wulff et al., 2006).

Penelitian tentang prevalensi dan tingkat kontaminasi $L$. monocytogenes pada udang vaname yang berasal dari tambak, bahan baku di bagian penerimaan, dan produk akhir di bagian proses pembekuan di UPI, yang ketiganya merupakan satu alur proses pengolahan baru pertama kali dilaporkan di Indonesia. Hasil penelitian ini menunjukkan adanya peluang kontaminasi $L$. monocytogenes terhadap produk akhir yang berasal dari ketiga rantai tersebut. Beberapa hasil penelitian serupa, selain di Indonesia, menunjukkan bahwa prevalensi $L$. monocytogenes pada produk udang di tambak sebesar $11 \%$ (Motes, 1991), di bahan baku dengan kisaran 4-20,9\% (Fallah et al., 2013; Gudmundsdóttir et al., 2006), dan produk akhir dengan kisaran 5,6-26,5\% (Fallah et al. 2013; Valdimarsson, Einarsson, Gudbjörnsdottir \& Magnusson, 1998).

\section{Tingkat Kontaminasi Listeria monocytogenes}

Berdasarkan hasil penelitian ini, tingkat kontaminasi L. monocytogenes diketahui berkisar 6,1$1100 \mathrm{APM} / \mathrm{g}$ (Tabel 1). Tingkat kontaminasi tertinggi L. monocytogenes pada udang adalah $1.100 \mathrm{APM} / \mathrm{g}$ yang terdeteksi pada udang yang berasal dari bahan baku di bagian penerimaan dan produk akhir di bagian proses pembekuan di UPI, sementara itu tingkat kontaminasi terendah adalah 6,1 APM/g yang berasal dari tambak.

Regulasi terkait tingkat kontaminasi $L$. monocytogenes pada produk perikanan di Indonesia diatur di dalam Peraturan Kepala BPOM No. 13/2019 tentang batas kontaminasi mikroba pada pangan olahan, yang menyatakan bahwa kontaminasi $L$. monocytogenes tidak diperbolehkan terdapat di dalam pangan (negatif/25 g). Sementara itu Codex Alimentarius Commission CAC/GL 61-2007 mengatur tingkat kontaminasi bakteri $L$. monocytogenes untuk pangan di dalam kriteria mikrobiologi yaitu negatif/25 g untuk pangan yang dapat mendukung pertumbuhan $L$. monocytogenes dan tidak ada pengendalian terhadap pertumbuhan bakteri sebelum dikonsumsi (CAC, 2007). Persyaratan ini diberlakukan oleh negara-negara di Uni Eropa, Australia, dan Selandia Baru. Amerika Serikat juga memberlakukan persyaratan negatif/25 g pada pangan siap konsumsi (FDA, 2011).

Hasil penelitian ini menunjukkan bahwa sebanyak 9/135 sampel udang yang terkontaminasi $L$. monocytogenes tidak memenuhi persyaratan sebagai pangan yang aman untuk dikonsumsi berdasarkan regulasi yang diterapkan di Indonesia maupun di negara lain. Jika dikaitkan dengan produk perikanan untuk pasar ekspor, keberadaan L. monocytogenes pada produk ekspor seperti udang akan mengakibatkan terjadinya kasus penolakan ekspor dan berdampak pada kerugian material bagi pelaku usaha dan menurunnya tingkat kepercayaan importir. Oleh karena itu perlu dilakukan upaya pengendalian untuk mencegah kontaminasi tersebut. L. monocytogenes dapat mencemari udang mulai dari lingkungan budidaya, proses pengolahan, hingga produk akhir. Pengetahuan tentang sumber bakteri ini di lingkungan budidaya maupun UPI menjadi sangat penting untuk dapat melakukan tindakan pengendalian. Program pembersihan dan desinfeksi yang terencana dengan baik di lingkungan dan peralatan pengolahan, implementasi Hazard Analysis Critical Control Point (HACCP), praktek berproduksi dan higiene yang baik, kualitas bahan baku udang, disain fasilitas pengolahan yang tidak memberi peluang tumbuhnya $L$. monocytogenes, serta pelatihan karyawan, merupakan langkah-langkah yang harus dilakukan untuk menurunkan peluang kontaminasi (Jami et al., 2014; Miettinen \& Wirtanen, 2005).

\section{KESIMPULAN}

Secara keseluruhan prevalensi $L$. monocytogenes di udang vaname yang merupakan komoditas ekspor adalah 6,7\% dengan tingkat kontaminasi 6,1-1.100 APM/g. Keberadaan L. monocytogenes pada udang vaname diketahui terjadi sejak udang di tambak, bahan baku di bagian penerimaan, dan produk akhir di UPI dengan prevalensinya berturut-turut 6,$1 ; 9,6$; dan $4 \%$. Penerapan GAP (Good Aquaculture Practices) pada budidaya udang vaname, HACCP dan GMP (Good Manufacturing Practices) selama pengolahan udang beku di UPI, serta sanitasi dan higiene selama penanganan dan transportasi dari tambak ke UPI menjadi faktor utama dalam menjamin mutu dan keamanan produk udang beku. Berdasarkan hasil penelitian ini, perlu dilakukan kajian secara detil mengenai sumber kontaminasi $L$. monocytogenes di sepanjang rantai pengolahan udang beku termasuk asal bahan baku (di tambak, pengepul, dan selama transportasi) untuk mengetahui dan menentukan titik kritis peluang kontaminasi L. monocytogenes. 


\section{UCAPAN TERIMAKASIH}

Penelitian ini dibiayai oleh DIPA Balai Besar Penelitian dan Pengembangan Pengolahan Produk dan Bioteknologi Kelautan dan Perikanan tahun 2015 dengan judul penelitian "Penelitan Peningkatan Jaminan Mutu Dan Keamanan Pangan". Dalam penyusunan artikel penelitian ini, Yusma Yennie, Gunawan, dan Farida Ariyani bertindak sebagai kontributor utama. Ucapan terima kasih diberikan kepada Unit Pelayanan Teknis (UPT) Badan Karantina Ikan, Pengendalian Mutu dan Keamanan Hasil Perikanan (BKIPM) atas bantuan dan kerjasamanya selama pelaksanaan penelitian.

\section{DAFTAR PUSTAKA}

Arumugaswamy, R. K., Ali, G. R. R., \& Abd Hamid, S. N. (1994). Prevalence of Listeria monocytogenes in foods in Malaysia. International Journal of Food Microbiology, 23(1), 117-121. doi: 10.1016/01681605(94)90227-5.

Aznar, R., \& Alarcón, B. (2003). PCR detection of Listeria monocytogenes: a study of multiple factors affecting sensitivity. Journal of applied microbiology, 95(5), 958-966. doi: 10.1046/j.1365-2672.2003.02066.x.

Beaufort, A., Rudelle, S., Gnanou-Besse, N., Toquin, M. T., Kerouanton, A., Bergis, H., ... \& Cornu, M. (2007). Prevalence and growth of $L$. monocytogenes in naturally contaminated cold-smoked salmon. Letters in Applied Microbiology, 44(4), 406-411.

Beleneva, I. A. (2011). Incidence and characteristics of Staphylococcus aureus and Listeria monocytogenes from the Japan and South China seas. Marine Pollution Bulletin, 62(2), 382-387.doi: 10.1016/ j.marpolbul.2010.09.024.

Bhaskar, N., Setty, T. M. R., Mondal, S., Joseph, M. A., Raju, C.V., Raghunath, B. S., \& Ananthaet, C. S. (1998). Prevalence of bacteria of public health significance in the cultured shrimp (Penaeus monodon). Food Microbiology, 15(5), 511-519. doi: 10.1006/fmic.1998.0186.

Botzler, R. G., Cowan, A. B., \& Wetzler, T. F. (1974). Survival of $L$. monocytogenes in soil and water. Journal of Wildlife Diseases, 10(3), 204-212. doi: 10.7589/00903558-10.3.204.

Badan Pengawas Obat dan Makanan (BPOM). (2019). Peraturan Badan Pengawas Obat Dan Makanan Nomor 13 Tahun 2019 tentang Batas Maksimal Kontaminasi Mikroba Dalam Pangan Olahan. 1-48.

Customer Acquisition Cost (CAC). (2007). Guidelines on the application of general principles of food hygiene to the control of Listeria monocytogenes in foods. CAC/ GL 61-2007. http://www.codexalimentarius.net/ download/standards/10740/ CXG_061e.pdf.

Calo-Mata, P., Arlindo, S., Boehme, K., de Miguel, T., Pascoal, A., \& Barros-Velazquez, J. (2008). Current applications and future trends of lactic acid bacteria and their bacteriocins for the biopreservation of aquatic food products. Food Bioprocess Technol., 1, 43-63.

Chaturongkasumrit, Y., Takahashi, H., Keeratipibul, S., Kuda, T., \& Kimura, B. (2011) The effect of polyurethane belt surface roughness on $L$. monocytogenes biofilm formation and its cleaning efficiency. Food Control, 22(12), 1893-1899. doi: 10.1016/j.foodcont.2011.04.032.

Chen, M., Wu, Q., Zhang, J., Wu, S., \& Guo, W. (2015). Prevalence, enumeration, and pheno- and genotypic characteristics of $L$. monocytogenes isolated from raw foods in South China. Frontiers in microbiology, 6, 1-12. doi: 10.3389/fmicb.2015.01026.

Cordano, A. M. \& Rocourt, J. (2001) Occurrence of Listeria monocytogenes in food in Chile. International Journal of Food Microbiology, 70(1-2), 175-178. doi: 10.1016/ s0168-1605(01)00533-5

Destro, M. T., Leitao, M. F. F., \& Farber, J. M. (1996). Use of molecular typing methods to trace the dissemination of Listeria monocytogenes in a shrimp processing plant. Applied and Environmental Microbiology, 62(2), 705-711. doi: 10.1128/ aem.62.2.705-711.1996.

El-Shenawy, M. A., \& El-Shenawy, M. A. (2006). Listeria spp. in the coastal environment of the Aqaba Gulf, Suez Gulf and the Red Sea. Epidemiology \& Infection, 134(4), 752-757. doi: 10.1017/S0950268805005601

Embarek, P. K. B. (1994). Presence, detection and growth of $L$. monocytogenes in seafoods: a review. journal of food microbiology, 23(1), 17-34. doi: 10.1016/01681605(94)90219-4

Esteban, J. I., Oporto, B., Aduriz, G., Juste, R. A. \& Hurtado, A. (2009). Faecal shedding and strain diversity of Listeria monocytogenes in healthy ruminants and swine in Northern Spain. BMC Veterinary Research, 5(1), 1-10. doi: 10.1186/1746-6148-5-2

Food and Drug Administration (FDA). (2011). Fish and fishery products hazards and controls guidance. U.S. Department of Health and Human Services, Public Health Service, Food and Drug Administration USA. h t t p : / / w w w.fda.gov/downloads/food/ guidanceregulation/ucm251970.pdf.

Fallah, A. A., Saei-Dehkordi, S. S., \& Mahzounieh, M. (2013). Occurrence and antibiotic resistance profiles of $L$. monocytogenes isolated from seafood products and market and processing environments in Iran. Food control, 34(2), 630-636. doi: 10.1016/ j.foodcont.2013.06.015.

Fenlon, D. R. (1999). L. monocytogenes in the Natural Environment, 21-38. In E. T. Ryser and E. H. Marth (ed.), Listeria listeriosis and food safety, 2nd ed. Marcel Decker, Inc., New York, N.Y.

Franciosa, G., Tartaro, S., Wedell-Neergaard, C., \& Aureli, P. (2001). Characterization of $L$. monocytogenes strains involved in invasive and noninvasive listeriosis outbreaks by pcr-based fingerprinting techniques. Applied and Environmental Microbiology, 67(4), 1793-1799. doi:10.1128/aem.67.4.17931799.2001. 
Gambarin, P., Magnabosco, C., Losio, M. N., Pavoni, E., Gattuso, A., Arcangeli, G,. \& Favretti, M. (2012). L. monocytogenes in ready-to-eat seafood and potential hazards for the consumers. International Journal of Microbiology, 2012, 1-10. doi: 10.1155/2012/497635.

Gandhi, M., \& Chikindas, M. L. (2007). Listeria: A foodborne pathogen that knows how to survive: Review. International journal of food microbiology, 113(1), 1-15. doi:10.1016/j.ijfoodmicro.2006.07.008

Gawade, L., Barbuddhe, S. B., \& Bhosle, S. (2010). Isolation and confirmation of Listeria species from seafood of Goa region by polymerase chain reaction. IIndian journal of microbiology, 50(4), 385-389. doi: 10.1007/s12088-011-0064-y

Ghanbari, M., Jami, M., Domig, K. J., \& Kneifel, W. (2013). Seafood biopreservation by lactic acid bacteria - a review. LWT - Food Sci Technol, 50(2), 315-24.

Gram L. (2001). Potential hazards in cold-smoked fish: Listeria monocytogenes. J. Food Sci., 66, 1072-1081.

Gudbjörnsdottir, B., Suihko, M. L., Gustavsson, P., Thorkelsson, G., Salo, S., Sjöberg, A. M., ... \& Bredholt, $S$. (2004). The incidence of $L$. monocytogenes in meat, poultry and seafood plants in the Nordic countries. Food Microbiology, 21(2), 217-225. doi:10.1016/S0740-0020(03)00012-1

Gudmundsdóttir, S., Gudbjörnsdóttir, B., Lauzon, H. L., Einarsson, H., Kristinsson, K. G., \& Kristjánsson, M. (2005). Tracing L. monocytogenes isolates from coldsmoked salmon and its processing environment in Iceland using pulsed-field gel electrophoresis. International journal of food microbiology, 101(1), 4151. doi: 10.1016/j.ijfoodmicro.2004.08.023.

Gudmundsdóttir, S., Gudbjörnsdóttir, B., Einarsson, H., Kristinsson, K. G., \& Kristjansson, M. (2006). Contamination of cooked peeled shrimp (Pandalus borealis) by $L$. monocytogenes during processing at two processing plants. Journal of Food Protection, 69 (6), 1304-1311. doi: 10.4315/0362-028x-69.6.1304

Hansen, C. H., Vogel, B. F. \& Gram, L. (2006). Prevalence and survival of $L$. monocytogenes in danish aquatic and fish-processing environments. Journal of food protection, 69(9), 2113-2122. doi: 10.4315/0362$028 \mathrm{x}-69.9 .2113$

Hitchins, A. D. (2003). FDA-BAM online: Detection and enumeration of Listeria monocytogenes in foods. <http://www.cfsan.fda.gov/webam/bam-10.html>.

Hites, R. A., Foran, J. A., Carpenter, D. O., Hamilton, M. C., Knuth, B. A., \& Schwager, S. J. (2004). Global assessment of organic contaminant in farmed salmon. Science, 303(5655), 226-229. doi: 10.1126/ science. 1091447

Jadhav, S., Bhave, M., \& Palombo, E. A. (2012). Methods used for the detection and subtyping of Listeria monocytogenes. Journal of microbiological methods, 88(3), 327-341. doi: 10.1016/j.mimet.2012.01.002.

Jami, M., Ghanbari, M., Zunabovic, M., Domig, K. J., \& Kneifel, W. (2014). L. monocytogenes in aquatic food products-a review. Comprehensive Reviews in Food Science and Food Safety, 13(5), 798-813. doi: 10.1111/1541-4337.12092
Lappi, V. R., Ho, A., Gall, K. \& Wiedmann, M. (2004). Prevalence and growth of Listeria on naturally contaminated cold-smoked salmon over 28 days of storage at 4 degrees $C$. Journal Food Protection, $67(5), 1022-1026$. doi: 10.4315/0362-028x67.5 .1022

Liu, C., Mou, J., \& Su, Y. C. (2016). Behavior of Salmonella and Listeria monocytogenes in raw yellowfin tuna during cold storage. Foods, 5(1), 1-9. doi: 10.3390/ foods5010016

Lyautey, E., Lapen, D. R., Wilkes, G., McCleary, K., Pagotto, F., Tyler, K., ... \& Topp, E. (2007). Distribution and characteristics of Listeria monocytogenes isolates from surface waters of the south nation river watershed, Ontario, Canada. Applied and Environmental Microbiology, 73(17), 5401-5410. doi: 10.1128/aem.00354-07

Miettinen, H., \& Wirtanen, G. (2005). Prevalence and location of $L$. monocytogenes in farmed rainbow trout. International Journal of Food Microbiology, 104(2), 135-143. doi: 10.1016/j.ijfoodmicro.2005.01.013

Miettinen, H., \& Wirtanen, G. (2006). Ecology of Listeria spp. in a fish farm and molecular typing of $L$. monocytogenes from fish farming and processing companies. International Journal of Food Microbiology, 112(2), 138-146. doi: 10.1016/ j.ijfoodmicro.2006.06.016

Moharem, A. S., Charith Raj, A. P., \& Janardhan, G. R. (2007). Incidence of Listeria species in seafood products of Mysore, India. Journal of food safety, 27(4), 362-372. doi: 10.1111/j.1745-4565.2007.00085.x

Motes, M. L. (1991). Incidence of Listeria spp. in shrimp, oysters, and estuarine waters. Journal of food protection, 54(3), 170-173. doi: 10.4315/0362-028X54.3.170

Nakamura, H., Tokuda, Y., Sono, A., Koyama, T., Ogasawara, J., Hase, A., ... \& Nishikawa, Y. (2006). Molecular typing to trace $L$. monocytogenes isolated from cold-smoked fish to a contamination source in a processing plant. Journal Food Protection, 69(4), 835-41. doi: 10.1016/j.ijfoodmicro.2004.02.010

Norhana, M. N. W., Pool, S. E., Deeth, H. C., \& Dykes, G. A. (2010) Prevalence, persistence and control of Salmonella and Listeria in shrimp and shrimp products: a review. Food Control, 21(4), 343-361. doi: 10.1016/j.foodcont.2009.06.020.

Norton, D. M., McCamey, M. A., Gall, K. L., Scarlett, J. M., Boor, K. J., \& Wiedmann, M. (2001). Molecular studies on the ecology of $L$. monocytogenes in the smoked fish processing industry. Applied and Environmental Microbiology, 67(1), 198-205. doi: 10.1128/ AEM.67.1.198-205.2001

Palumbo, D., lannacone, M., Porta, A., \& Capparelli, R. (2010). Experimental antibacterial therapy with puroindolines, lactoferin and lysozyme in Listeria monocytogenes-infected mice. Microbes and Infection, 12(7), 538-545. doi: 10.1016/ j.micinf.2010.03.010

Parihar, V. S., Barbuddhe, S. B., Danielsson-Thm, M. L., \& Tham, W. (2008). Isolation and characterization of 
Listeria species from tropical seafoods. Food Control, 19(6), 566-9. doi: 10.1016/j.foodcont.2007.06.009

Paziak-Domanska, B., Boguslawska, E., WieckowskaSzakiel, M., Kotlowski, R., Rózalska, B., Chmiela, M., ... \& Rudnicka, W. (1999). Evaluation of the API test, phosphatidylinositol-specific phospholipase C activity and PCR method in identification of $L$. monocytogenes in meat foods. FEMS Microbiol Letters, 171(2), 209214. doi: 10.1111/j.1574-6968.1999.tb13434.x.]

Rahayu, W. P., Rinanti, R., Nurjanah, S., \& Nurwitri, C. C. (2016). Indentifikasi Listeria monocytogenes pada kerang hijau dan kerang darah. Jurnal Pengolahan Hasil Perikanan Indonesia, 19(3), 329-338. doi: 10.17844/jphpi.2016.19.3.329

Riedo, F. X., Pinner, R. W., Tosca, M. D. L., Cartter, M. L., Graves, L. M., Reeves, M. W., ... \& Broome, C. (1994). A point-source foodborne outbreak: Documented incubation period and possible mild illness. Journal of Infectious Diseases, 170(3), 693-696. doi:10.1093/ infdis/170.3.693

Rørvik, L. M. (2000). L. monocytogenes in the coldsmoked salmon industry. International Journal of Food Microbiology, 62(3), 183-190. doi: 10.1016/ s0168-1605(00)00334-2

Rørvik, L. M., Caugant, D. A., \& Yndestad, M. (1995). Contamination pattern of $L$. monocytogenes and other Listeria spp. in a salmon slaughterhouse and smoked salmon processing plant. International journal of food microbiology, 25(1), 19-27. doi: 10.1016/01681605(94)00080-p

Schaffter, N., \& Parriaux, A. (2002). Pathogenic-bacterial water contamination inmountainous catchments. Water Research, 36(1), 131-139. doi: 10.1016/ s0043-1354(01)00242-1

SNI ISO 11290-1. (2012). Mikrobiologi bahan pangan dan pakan. Metode horizontal untuk deteksi dan enumerasi L. monocytogenes. Bagian 1: Metode deteksi.

Sotgiu, G., Muresu, N., Dettori, M., Mura, E., Cossu, A., Dolores Masia, M., ... \& Piana, A. (2019). Case Report: A case of Listeria monocytogenes ST-219 meningo-encephalitis. Journal of Environmental Research and Public Health, 16(1), 8, doi: 10.3390/ ijerph16010008

Thimothe, J., Nightingale, K. K., Gall, K., Scott, V. N., \& Wiedmann, M. (2004). Tracking of L. monocytogenes in smoked fish processing plants. Journal of food protection, 67(2), 328-341. doi: 10.4315/0362-028X67.2 .328
Thimothe, J., Walker, J., Suvanich, V., Gall, K. L., Moody, M.W., \& Wiedmann, M. (2002). Detection of Listeria in crawfish processing plants and in raw, whole crawfish and processed crawfish (Procambarus spp.). JJournal of food protection, 65(11), 1735-1739. doi: 10.4315/0362-028x-65.11.1735

Valdimarsson, G., Einarsson, H. Gudbjörnsdottir, B., \& Magnusson, H. (1998). Microbiological quality of Icelandic cooked-peeled shrimp (Pandalus borealis). Journal of Food Microbiology, 45(2), 157-161. doi: 10.1016/s0168-1605(98)00149-4

Vogel, B. F., Huss, H. H., Ojeniyi, B., Ahrens, P., \& Gram, L. (2001). Elucidation of $L$. monocytogenes contamination routes in cold-smoked salmon processing plants detected by DNA-based typing methods. Applied and Environmental Microbiology, 67(6), 2586-2595. doi: 10.1128/AEM.67.6.2586-2595.2001

Wang, F., Jiang, L., Yang, Q., Han, F., Chen, S., Pu, S., ... \& $\mathrm{Ge}, \mathrm{B} .(2011)$. Prevalence and antimicrobial susceptibility of major foodborne pathogens in imported seafood. Journal of food protection, 74(9), 1451-1461. doi: 10.4315/0362-028X.JFP-11-146

Wulff, G., Gram, L., Ahrens, P., \& Vogel, B. F. (2006). One group of genetically similar $L$. monocytogenes strains frequently dominates and persists in several fish slaughter and smokehouses. Applied and Environmental Microbiology, 72(6), 4313-4322. doi: 10.1128/AEM.02288-05

Yadollahi, S., Momtaz, H., Doudi, M., Taj bakhsh, E. (2013). Isolation and characterization of Listeria species and determines $L$. monocytogenes serotypes in fresh fish, shrimp, crab and lobster in Isfahan and Shahrekord, Iran. International Journal of Advanced Biological and Biomedical Research, 1(5), 493-504.

Yan, H., Neogi, S. B., Mo, Z., Guan, W., Shen, Z., Zhang, S., ... \& Zhong, N. (2010). Prevalence and characterization of antimicrobial resistance of foodborne Listeria monocytogenes isolates in Hebei province of Northern China, 2005-2007. International Journal of Food Microbiology, 144(2), 310-316. doi: 10.1016/j.ijfoodmicro.2010.10.015

Yuswita, E., Nurjanah, S., \& Rahayu, W. P. (2016). Identifikasi Listeria spp. pada pangan jajanan berbasis ikan di kota Bogor. Teknologi dan Industri Pangan, 27(1), 10-16. doi: 10.6066/jtip.2016.27.1.10

Zhu, M., Du, M., Cordray, J., \& Ahn, D. U. (2005). Control of $L$. monocytogenes contamination in ready-to-eat meat products. Comprehensive Reviews in Food Science and Food Safety, 4(2). 